\title{
Setting the Phosphorus Boundaries for Greek Natural Shallow and Deep Lakes for Water Framework Directive Compliance
}

\author{
Ifigenia Kagalou $^{1}$ (D), Chrysoula Ntislidou ${ }^{2} \mathbb{D}$, Dionissis Latinopoulos ${ }^{1}\left(\mathbb{D}\right.$, Dimitra Kemitzoglou $^{3}$, \\ Vasiliki Tsiaoussi ${ }^{3}$ and Dimitra C. Bobori ${ }^{2, *(D)}$ \\ 1 Department of Civil Engineering, School of Engineering, Democritus University of Thrace, \\ 67100 Xanthi, Greece; ikagkalo@civil.duth.gr (I.K.); dlatinop@civil.duth.gr (D.L.) \\ 2 Department of Zoology, School of Biology, Aristotle University of Thessaloniki, 54124 Thessaloniki, Greece; \\ ntislidou@bio.auth.gr \\ 3 The Goulandris Natural History Museum, Greek Biotope/Wetland Centre (EKBY), 57001 Thermi, Greece; \\ dimitra@ekby.gr (D.K.); vasso@ekby.gr (V.T.) \\ * Correspondence: bobori@bio.auth.gr
}

check for updates

Citation: Kagalou, I.; Ntislidou, C.; Latinopoulos, D.; Kemitzoglou, D.; Tsiaoussi, V.; Bobori, D.C. Setting the Phosphorus Boundaries for Greek Natural Shallow and Deep Lakes for Water Framework Directive Compliance. Water 2021, 13, 739. https:/ / doi.org/ 10.3390/w13050739

Academic Editors:

Nikolaos Skoulikidis and Xing Fang

Received: 22 January 2021

Accepted: 4 March 2021

Published: 9 March 2021

Publisher's Note: MDPI stays neutral with regard to jurisdictional claims in published maps and institutional affiliations.

Copyright: (c) 2021 by the authors. Licensee MDPI, Basel, Switzerland. This article is an open access article distributed under the terms and conditions of the Creative Commons Attribution (CC BY) license (https:/ / creativecommons.org/licenses/by/ $4.0 /)$.

\begin{abstract}
Eutrophication caused by nutrient enrichment is a predominant stressor leading to lake degradation and, thus, the set-up of boundaries that support good ecological status, the Water Framework Directive's main target, is a necessity. Greece is one of the Member States that have recorded delays in complying with the coherent management goals of European legislation. A wide range of different statistical approaches has been proposed in the Best Practice Guide for determining appropriate nutrient thresholds. To determine the nutrient thresholds supporting the good status of natural Greek lakes, the phytoplankton dataset gathered from the national monitoring programme (2015-2020) was used for shallow and deep natural lakes. The regression analyses were sufficient and robust in order to derive total phosphorus thresholds that ranged from 20 to $41 \mu \mathrm{g} / \mathrm{L}$ in shallow and $15-32 \mu \mathrm{g} / \mathrm{L}$ in deep natural lake types. Nutrient boundaries that encompass the stressors these lakes are subject to, are essential in proper lake management design.
\end{abstract}

Keywords: eutrophication; phytoplankton; good-moderate boundary; nutrient thresholds; best practice guide

\section{Introduction}

The Water Framework Directive (WFD) [1] specifies that for surface waters to be at "Good Ecological Status (GES)", nutrient concentrations should not exceed the levels established so as to ensure the functioning of the ecosystem and the achievement of the values specified for the Biological Quality Elements (BQEs) [1]. Based on the review delivered by MARS project [2] about the stressors affecting European rivers, lakes, groundwater and transitional-coastal waters [3], it becomes clear that nutrient loading was a predominant stressor occurring in more than $70 \%$ of multiple stress situations [4], underlining the need for reduction of nutrient stress [5].

At the same time, the responses of BQEs to nutrient availability are complex and vary within and between water categories determined mainly by the hydromorphological characteristics of each category. Key lessons learned are that water bodies respond differently to nutrient enrichment depending on category, type and geographical location and that the influence of confounding factors on the underlying nutrient-biology relationship can also vary considerably [6-10]. This may lead to a "weak" or even to a wrong diagnosis of the cause(s) of failure to meet the ecological goals which in turn affects the suggested Program of Measures (PoMs) [11-13].

Consequently, a large list of metrics reflecting the aquatic biota response to nutrient enrichment has been developed to meet the WFD goals [6,14,15]. Regarding nutrient concentrations, the establishment of thresholds that would support the GES is a responsibility 
of each Member State (MS). Furthermore, establishing nutrient criteria has assumed greater importance as regulatory water agencies in numerous countries worldwide have extended their efforts to control eutrophication across all categories of water bodies [5,16-19].

Concerning lakes, their function and value are increasingly compromised due to human degradation, particularly anthropogenic eutrophication [20], while the primary goal for lake management is the reduction of nitrogen and phosphorous inputs from both external and internal loading [21-23]. Lakes' sensitivity to nutrients loading and their ability to retain nutrients depends strongly on their morphometry determining also the retention time.

During the recent decades, substantial achievements in nutrients reductions have been attained mainly through the reduction from point sources (sewage) but also through modifications in agricultural and forestry practices [24,25]. However, a general improvement in European lakes' ecological status is not obvious [26-28] with many lakes showing slow recovery [20], while it has been documented that sustainable lake restoration is difficult to achieve [22]. The main reasons can be found in the range of interconnected processes driving lakes' response to external and internal factors and in water column dynamics in response to critical processes as phosphorus concentrations change [29,30].

Given this complexity, it is essential to set appropriate nutrient boundaries for effective lake management, especially given the problems found in the later stages of management under WFD implementation [31]. Numerous approaches have been applied to evaluate the response of biological indices to nutrients. Traditionally, several relationships have been established between nutrients and phytoplankton metrics [32] obviously because concentrations of Phosphorus $(\mathrm{P})$ and Nitrogen $(\mathrm{N})$ limit the "yield" of phytoplankton biomass in a water body [23]. The statistical pressure-response relationship between phosphorus and eutrophication (as expressed by phytoplankton metrics) has been often recorded as stronger than that for nitrogen [8] and thus, it is not surprising that the majority of European MSs have already established boundary for P values [33]. Model approaches developed more than 20 years ago $[34,35]$ simulating BQEs responses to a given environmental gradient reflecting ecological condition set the basis for the contemporary WFD ecological quality classification. Different BQEs can act as pressure-respondents with complementary roles as proxies of structural and functional ecology [36]. In lakes, phytoplankton is the "fast responder" to eutrophication, while other BQEs are more sensitive to other pressures like hydromorphological or chemical ones $[14,15,17]$.

Following the progress of the above theories and approaches, nowadays, the updated best practice guide [37] is the major WFD tool to link nutrient concentrations with BQEs and to specific policy objectives in surface water. So far, this guide has been applied to different waterbodies using a variety of BQEs, such as in Central Baltic rivers using macrophytes and phytobenthos [38], Central Baltic lakes using macrophytes [9] and coastal/transitional waters with phytoplankton [39].

As Greece lagged behind in the development of WFD compliant methods for the ecological classification of all waterbodies' types, significant effort was put in place to fill the gap, which resulted in national methods being included in the European Intercalibration Decision in 2018 [40]. The first cycle of the River Basin Management Plans (RBMPs) (20092015) was drawn up by the Special Water Secretariat with important delays. The second one (1st Revision of the RBMPs) was published in 2017 [41], following the development of WFD compliant methodologies and an extensive consultation [42] along with a delay in adopting the proposed RBMPs [43]. It is worth noting that the progress in Europe was made without the contribution of Greece (Legal action for "non-communication") and that there was no data available in WISE for the 2nd RBMPs by 2018 [27].

Regarding specifically lake waterbodies, Greece is facing the problem of not having established boundaries for nutrients that can support the WFD goal of at least GES. According to the recommendations by the relevant European Commission Working Group (ECOSTAT) the reported range of boundary values should support the ecological status at specific water body types taking into consideration the complicated pressure-response 
relationships. This study aims at investigating the stressor-response relationship between phytoplankton community changes as expressed by Ecological Quality Ratio (EQR) and Total Phosphorus (TP) concentrations. A secondary aim of this research is to estimate the thresholds for TP using phytoplankton as the main BQE, exploiting all available relative literature and official WFD tools focusing at two major national types. In addition, we attempted to raise our awareness in system understanding related to the pressures posed by nutrient input providing possibly the context for better monitoring and management.

\section{Materials and Methods}

\subsection{Datasets}

In Greece, 50 lakes with an area of more than $0.5 \mathrm{~km}^{2}$ are included in the National monitoring network, 22 of which are natural and are divided in three types [44]. The rest are artificial or unique lakes due to special chemical conditions and geological descriptors. The natural lakes of the Monitoring network in Greece are grouped into 3 types: (a) warm monomictic, deep natural lakes with mean depth $>9$ m (type GR-DNL, 7 lakes); (b) polymictic, shallow lakes with mean depth 3-9 m (type GR-SNL, 8 lakes); (c) very shallow lakes $<3 \mathrm{~m}$ (type GR-VSNL, 7 lakes). Five national assessment methods have been adopted so far for phytoplankton [44], macroinvertebrates (profundal/sublittoral [45] and littoral [46]), fish [47] and macrophytes [48]. The dataset contained TP ( $\mu \mathrm{g} / \mathrm{L})$ values and EQR values of phytoplankton, macrophytes and zoobenthos indices. Phytoplankton and water samplings took place in the pelagic zone, covering the euphotic zone water column ( $2.5 \times$ Secchi disk depth) using a Nansen type sampler [49]. Benthic macroinvertebrates were sampled using the three-minute kick/sweep method [50] with standard hand net ( $500 \mu \mathrm{m}$ mesh size) at the littoral zone of the lake (up to $1.2 \mathrm{~m}$ depth of water). Regarding macrophytes, the belt transect-mapping method was applied and sampling within each transect followed the guidelines proposed by [51,52]. The EQR values for each BQE were calculated as mean values, according to the respective WFD compliant national assessment methods $[40,44,46,48,49]$ following the guidelines of WFD. The TP concentrations were determined after persulfate digestion [53]. Seasonal data were averaged to mean annual TP values in order to avoid uneven distribution of data both within and across months. These mean annual values were further used in the statistical analyses. In total, for GR-SNL, the dataset comprised 36 lake years with phytoplankton, 12 with macrophyte and 8 with zoobenthos. For GR-DNL, the dataset comprised 16 lake years with phytoplankton, 6 with macrophyte and 4 lake years with zoobenthos. With regard to the GR-SNL type it is noted that the 36 lake years with phytoplankton were formed by 134 samples, while for the GR-DNL one 58 phytoplankton samples were summed. In particular, a lake-year phytoplankton EQR was calculated by averaging data from three or four phytoplankton samples taken during the warm season of that year [44,49]. The TP concentrations of $15 \mu \mathrm{g} / \mathrm{L}$ and $12 \mu \mathrm{g} / \mathrm{L}$ (mean annual values) had been previously considered as pressure criteria to determine potential reference sites for GR-SNL and GR-DNL types, respectively [44,48]. As reference sites, only few were designated and these provided the dataset with reference values for $\mathrm{TP}$ in each lake type.

\subsection{Data Check}

A technical guidance has been designed to describe a variety of statistical approaches for establishing the concentrations of nutrients to support GES [37]. Prior to the analyses, data were checked to identify outliers using box plots and eliminating them from some analysis. As outliers were selected the data points that were above or below the 0.975 percentile of residuals. However, the exclusion or inclusion of outliers was evaluated for each statistical approach. Moreover, we attempted to determine the relationship between pressure and response using Generalized Additive Models (GAMs) and to predict a sufficient coverage of the gradient of disturbance. The approach was to construct a scatter plot and then to fit a GAM model to the data set (EQR vs. TP), checking for linearity. An adequate number of nutrient data across ecological quality classes, especially High $(\mathrm{H})$, 
Good (G) and Moderate (M), were identified using box plots. Prior to some analysis (e.g., Univariate linear regression), nutrient concentrations were $\log 10$ transformed to reduce right skewness distribution.

The BQEs of macrophytes and benthic macroinvertebrates were excluded from the analysis due to the insufficient number of samples and inadequate coverage of the gradient. Regarding the macrophytes, only 12 (High: $n=1$, Good: $n=5$, Moderate: $n=4$, Poor: $n=2$ ) and six (High: $n=1$, Good: $n=5$ ) EQRs were included in the dataset for GR-SNL and GR-DNL types, respectively. The same problem was noticed for benthic macroinvertebrate dataset, as it was compiled with few EQRs for both lake types (i.e., GR-SNL; Good: $n=2$, Moderate: $n=5$, Poor: 1 ; GR-DNL; Good: $n=2$, Moderate: $n=2$ ). Thus, the analysis focused on phytoplankton BQE for types GR-SNL (8 lakes, 10 sampling stations) and GR-DNL (7 lakes, 8 sampling stations) (Figure 1).

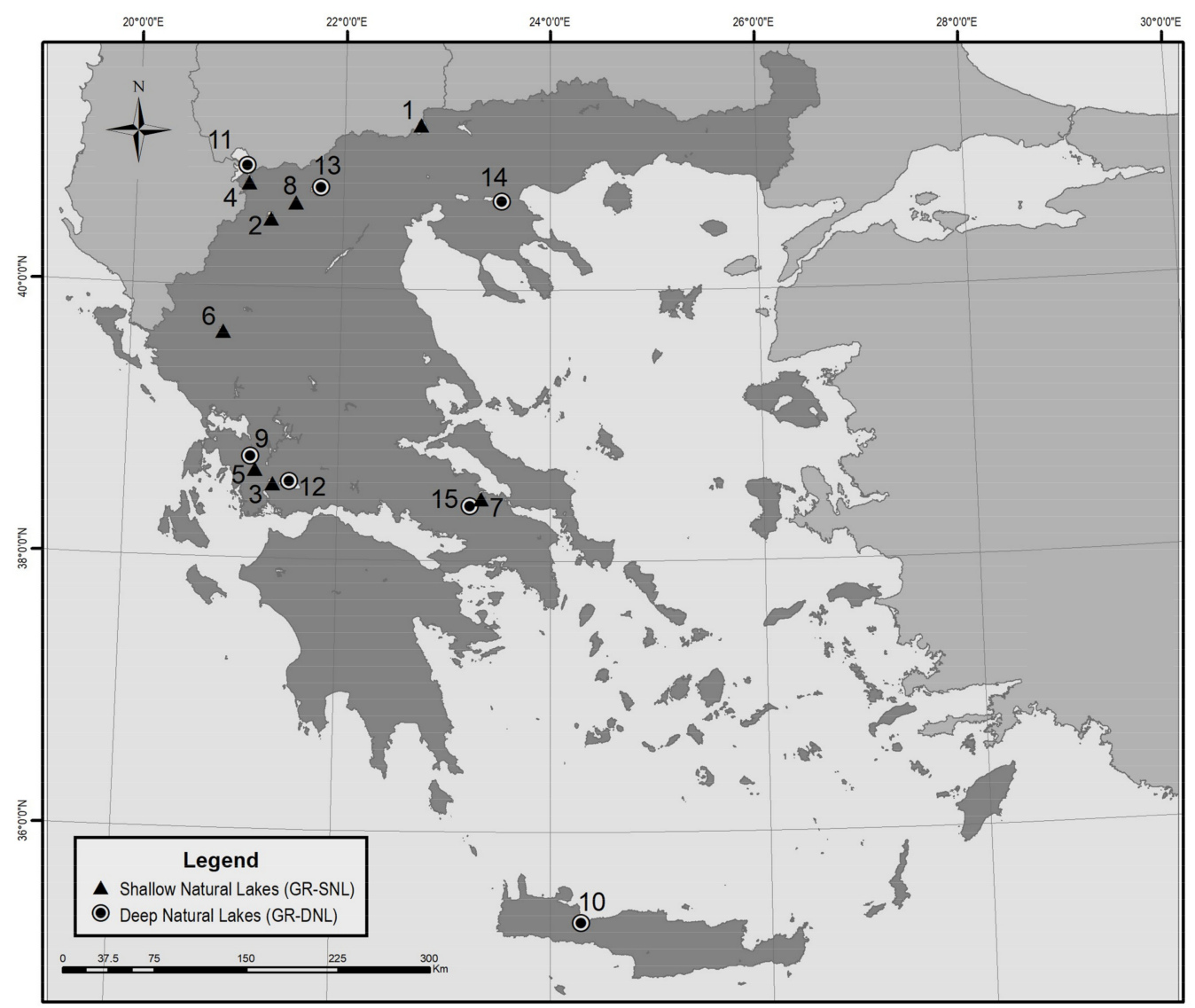

Figure 1. Lake types of the Greek Monitoring Network. Greek Shallow Natural Lakes (GR-SNL): 1. Doirani, 2. Kastoria, 3. Lysimacheia, 4. Mikri Prespa, 5. Ozeros, 6. Pamvotida, 7. Paralimni, 8. Zazari; Greek Deep Natural Lakes (GR-DNL): 9. Amvrakia, 10. Kourna, 11. Megali Prespa, 12. Trichonida, 13. Vegoritida, 14. Volvi, 15. Yliki.

\subsection{Methods for Estimating Nutrient Threshold Concentrations}

The recommended technical guidance outlines a well-established methodology and comes with a toolkit [37], which provides the statistical approaches in the form of $\mathrm{R}$ scripts [54]. Detailed instructions about the approaches are included in the technical guidance [37]. Therefore, only a brief synopsis is presented below:

\section{i. Regression analyses}

Univariate linear regression: the most common approach assumes a continuous linear relationship between EQR and nutrient concentrations. Specifically, two ordinary least squares linear regressions between EQR and $\log \mathrm{TP}$, where each variable was alternatively considered as independent and a Ranged Major Axis (RMA) regression (type II regression) 
were performed. The latter assumes equal uncertainty in measurement of both variables (EQR and TP) either of which could be considered as the independent variable. The assumptions of linear models (i.e., homoscedasticity and normality of residuals) were checked using plot function of model and gvlma package in R [54].

Linear quantile regression: an alternative approach when wedge-shape or invertedwedge distribution is noticed in the dataset. Under these circumstances, the linear quantile regression aims to predict different aspects of the distribution of points. In both lake types, a wedge-shape or an inverted-wedge data distribution were not detected and thus, the predicted nutrient thresholds from this approach could not be estimated.

\section{ii. Categorical methods}

Box plots: the continuous variable EQR is divided into five categorical ecological status classes using box plots. Thus, the concentrations from a certain class (e.g., moderate) could be expressed as a distribution where an upper or a lower quantile might be selected as a threshold. Additionally, the average of the median of adjacent classes (e.g., the average median of "good status" with median of "moderate status") and average of adjacent quartiles (75th percentile of "good status" and 25th percentile of "moderate status") were also tested. Among the distributions in adjacent classes, there should be a significant difference (non-parametric Wilcoxon test, $p<0.05$ ), otherwise the boundaries must be treated with extreme caution.

Binary logistic regression: an alternative approach that handles EQR as a categorical variable where a logistic model is fitted between categorical data using a binary response (i.e., in the case of the high-good criteria: "biology high" $=0$ and "biology good or worse" $=1$; in the case of good-moderate criteria: "biology good or better" $=0$ and "biology moderate or worse" =1) and log TP. Predicted nutrient threshold was presented for 0.5 probability of being in "moderate or worse" status or in "good or worse" for goodmoderate and high-good criteria, respectively. Additionally, probabilities of 0.25 and 0.75 were also estimated to indicate different risks of failing to meet the desired standard [31].

Minimisation of mismatch of classification: this method demonstrates the nutrient threshold that gives the lowest mismatch between status and the nutrient concentration. A bootstrap approach was applied to determine the lowest mismatch of classifications. For each dataset, $75 \%$ of the data were randomly chosen and the proportions of misclassification determined. Then, the loess models were fitted to the data to establish the nutrient concentration where the cross-over point between the two curves was identified. This was repeated 50 times and the mean nutrient concentration was determined. This method is the least sensitive to outliers and non-linear relationships.

Decision tree: a technique which resamples data into subsets that maximize the homogeneity within the set and the heterogeneity outside the set to build a tree-like structure. The decision tree separated the data into two subsets by calculating the best feature split determined by classes (High, Good, Moderate), which continued until all observations were classified.

\subsection{Selection of the Method}

The selection of the most suitable approach was based on the roadmap included in the technical guidance [37]. The first option considers the linear models and the strength of the relationship between EQR values and nutrients. To establish nutrient thresholds, the data should span into four ecological quality classes (High, Good, Moderate, Poor). Moreover, the strength of the linear relationship should be strong $\left(R^{2}>0.36\right)$ [37]. Regarding the type II linear regression, the correlation value ( $\mathrm{r}$ ) should be more than |0.6। [55]. If the linear regression is weak $\left(R^{2}<0.36\right.$ or $\left.r<0.6\right)$, then categorical approaches should be applied to the dataset. 


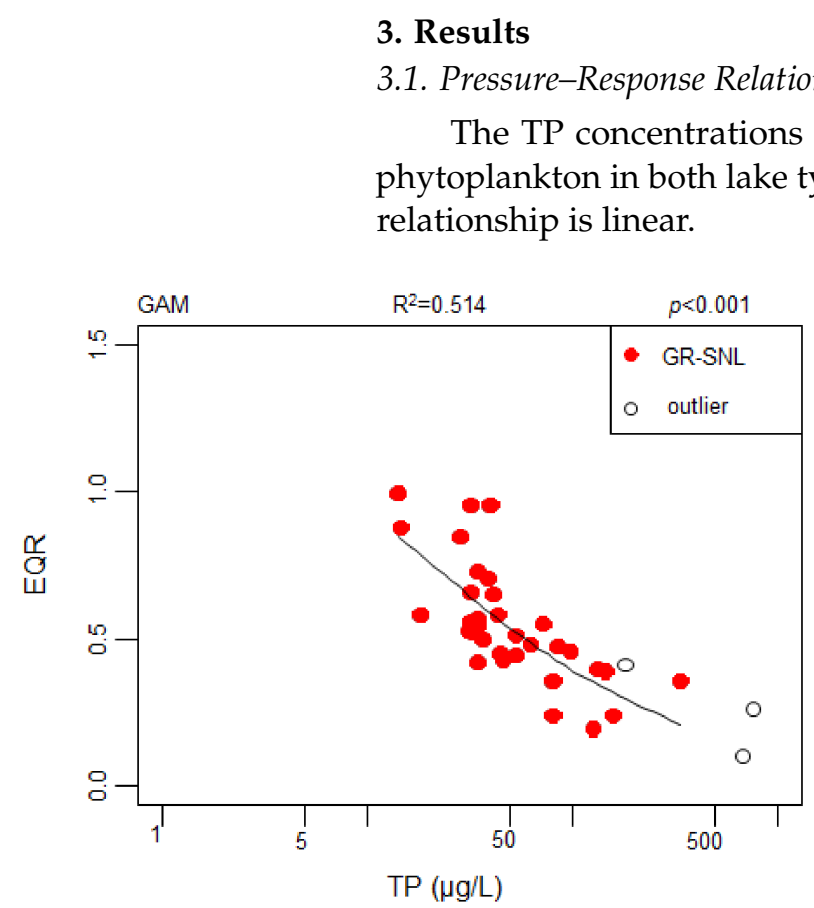

(a)

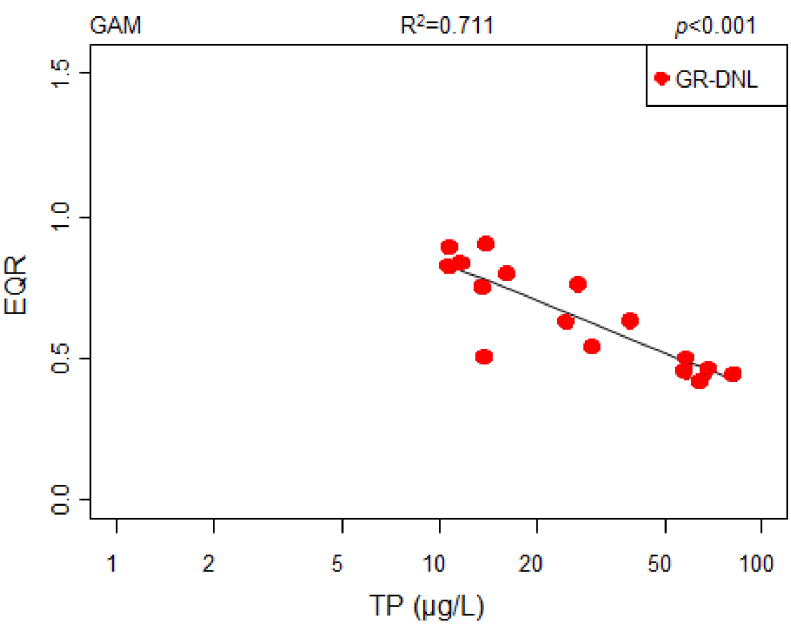

(b)

Figure 2. Scatter plot showing relationship between Ecological Quality Ratio (EQR) values of phytoplankton and Total Phosphorus (TP, $\mu \mathrm{g} / \mathrm{L}$ ) with fitted Generalized Additive Models (GAM) in (a) Greek Shallow Natural Lakes (GR-SNL) and; (b) Greek Deep Natural Lakes (GR-DNL). Open circles are outliers not used to fit model.

\subsection{Univariate Regression Models}

All the assumptions of linear models were met and thus, the linear regression models were applied. For both lake types, linear relationships between TP and the EQR values of phytoplankton were meaningful with robust $\mathrm{r}^{2}$ values $(p<0.001)$ allowing to establish nutrient boundaries (Table 1). Regarding the GR-SNL type, the RMA regression relationship between TP and phytoplankton was significant $(\mathrm{r}=-0.71)$ and predicted a good-moderate threshold of $41 \mu \mathrm{g} / \mathrm{L}$ with a range of $27-56 \mu \mathrm{g} / \mathrm{L}$ and high-good threshold of $20 \mu \mathrm{g} / \mathrm{L}$ (range: 13-28 $\mu \mathrm{g} / \mathrm{L}$ ) (Table 1). For the GR-DNL type, the relationship (RMA regression, $\mathrm{r}=-0.84$ ) produced a lower good-moderate threshold of $32 \mu \mathrm{g} / \mathrm{L}$ (range: $28-38 \mu \mathrm{g} / \mathrm{L}$ ) and high-good threshold of $13 \mu \mathrm{g} / \mathrm{L}$ (range: 11-15 $\mu \mathrm{g} / \mathrm{L}$ ) (Table 1).

Table 1. Summary of predicted values of Total Phosphorus (TP $\mu \mathrm{g} / \mathrm{L})$ concentration at the Good-Moderate (GM) and High-Good (HG) status per lake type (GR-SNL: Greek Shallow Natural Lakes and GR-DNL: Greek Deep Natural Lakes), obtained by regression analyses. OLS: Ordinary least squares, EQR: Ecological Quality Ratio, RMA: Ranged Major Axis, $n$ : number of samples. ${ }^{*}: p<0.001$.

\begin{tabular}{|c|c|c|c|c|c|c|c|c|c|}
\hline \multirow{2}{*}{ Lake Type } & \multirow{2}{*}{$\begin{array}{l}\text { Regression } \\
\text { Models }\end{array}$} & \multirow{2}{*}{$n$} & \multirow{2}{*}{$\mathbf{R}^{2}$} & \multicolumn{3}{|c|}{ GM TP $(\mu \mathrm{g} / \mathrm{L})$} & \multicolumn{3}{|c|}{ HG TP ( $\mu \mathrm{g} / \mathrm{L})$} \\
\hline & & & & Predicted & 25th & 75th & Predicted & 25th & 75th \\
\hline \multirow{3}{*}{ GR-SNL } & OLS EQR vs. TP & \multirow{3}{*}{36} & \multirow{3}{*}{0.512 * } & 39 & 22 & 54 & 15 & 9 & 21 \\
\hline & RMA EQR vs. TP & & & 41 & 27 & 56 & 20 & 13 & 28 \\
\hline & OLS TP vs. EQR & & & 44 & 30 & 62 & 27 & 18 & 38 \\
\hline \multirow{3}{*}{ GR-DNL } & OLS EQR vs. TP & \multirow{3}{*}{16} & \multirow{3}{*}{0.707 * } & 33 & 28 & 41 & 12 & 11 & 16 \\
\hline & RMA EQR vs. TP & & & 32 & 28 & 38 & 13 & 11 & 15 \\
\hline & OLS TP vs. EQR & & & 30 & 26 & 39 & 15 & 13 & 20 \\
\hline
\end{tabular}




\subsection{Box Plots}

In GR-SNL type, the box plots showed overlap in good and moderate classes (Wilcoxon test $p>0.05$, Figure 3a) while significant differences were noticed in GR-DNL type for all classes (Wilcoxon test $p<0.05$, Figure $3 b$ ). In Table 2 the potential thresholds for different quantiles are summarized.

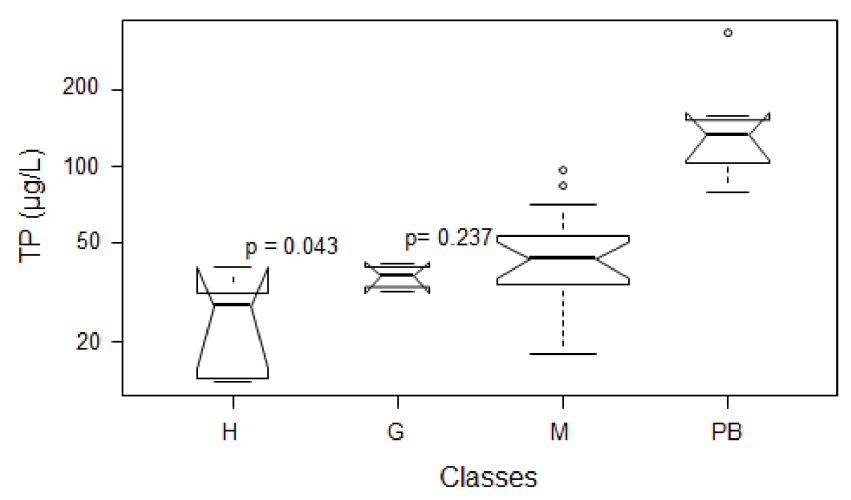

(a)

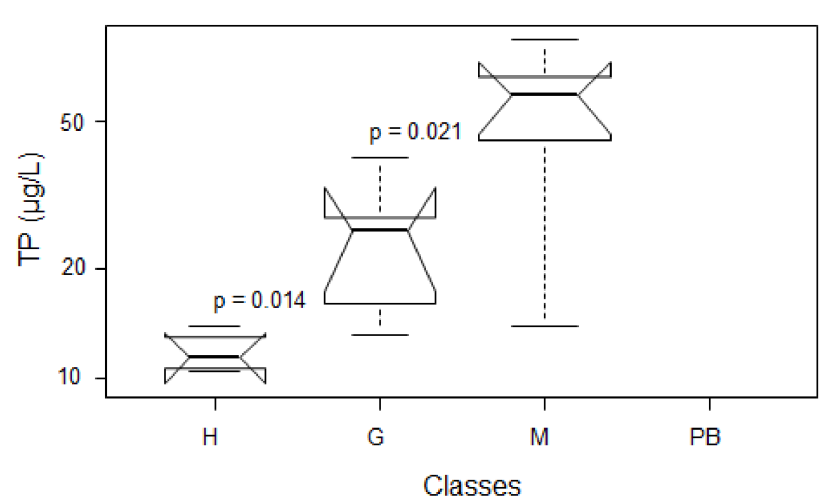

(b)

Figure 3. Box plots showing range of Total Phosphorus (TP, $\mu \mathrm{g} / \mathrm{L})$ concentrations by ecological classes (H: High, G: Good, M: Moderate, PB: Poor-Bad) in (a) Greek Shallow Natural Lakes (GR-SNL); (b) Greek Deep Natural Lakes (GR-DNL). The width of boxes is proportional to number of records in class. The $p$-values represent the significance of Wilcoxon test results.

Table 2. Summary of predicted values of Total Phosphorus (TP $(\mu \mathrm{g} / \mathrm{L})$ at different ecological classes per lake type (GR-SNL: Greek Shallow Natural Lakes and GR-DNL: Greek Deep Natural Lakes), obtained by box plots. NA: not applicable.

\begin{tabular}{|c|c|c|c|c|c|c|c|c|}
\hline \multirow{2}{*}{ Percentiles } & \multicolumn{4}{|c|}{ GR-SNL } & \multicolumn{4}{|c|}{ GR-DNL } \\
\hline & High & Good & Moderate & Poor/Bad & High & Good & Moderate & Poor/Bad \\
\hline 95th & 38 & 41 & 87 & 281 & 14 & 37 & 78 & NA \\
\hline 75th & 32 & 39 & 53 & 151 & 13 & 27 & 66 & NA \\
\hline 50th & 28 & 36 & 43 & 133 & 12 & 25 & 59 & NA \\
\hline 25th & 14 & 34 & 34 & 103 & 11 & 16 & 44 & NA \\
\hline 5th & 14 & 32 & 28 & 79 & 11 & 14 & 19 & NA \\
\hline $\begin{array}{l}\text { Average } \\
\text { quartiles }\end{array}$ & 33 & 36 & 93 & NA & 14 & 36 & NA & NA \\
\hline $\begin{array}{l}\text { Average } \\
\text { median }\end{array}$ & 32 & 40 & 88 & NA & 18 & 42 & NA & NA \\
\hline
\end{tabular}

\subsection{Binary Logistic Regression}

The binary logistic regressions of TP on phytoplankton data for the good-moderate and high-good thresholds for both lake types are presented in Figure 4. The good-moderate threshold corresponding to a $50 \%$ probability of being classified as moderate status or worse was $28.5 \mu \mathrm{g} / \mathrm{L}$ and $30.7 \mu \mathrm{g} / \mathrm{L}$ for GR-SNL and GR-DNL types, respectively (Figure 4a,b). Concerning the high-good threshold (50\% probability), the concentrations were $22.1 \mu \mathrm{g} / \mathrm{L}$ and $13.3 \mu \mathrm{g} / \mathrm{L}$ for GR-SNL and GR-DNL types, respectively (Figure 4c,d). 


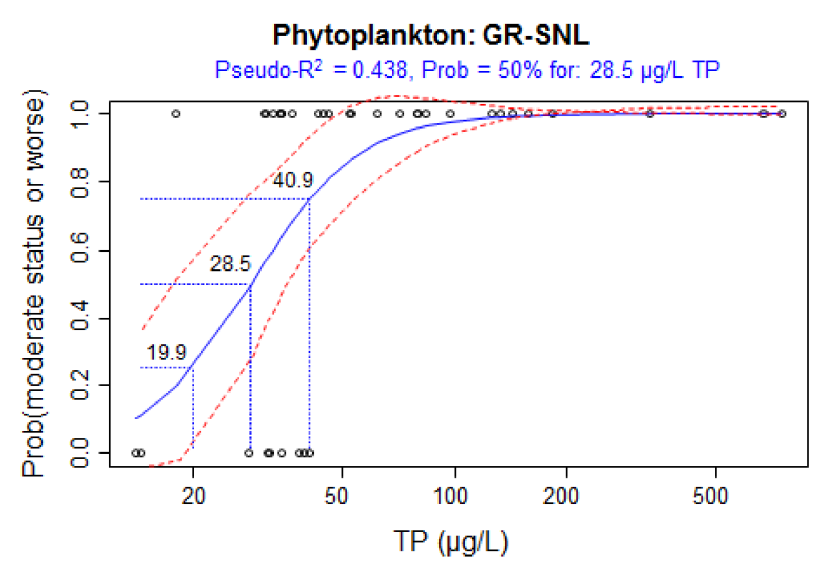

(a)

Phytoplankton: GR-SNL

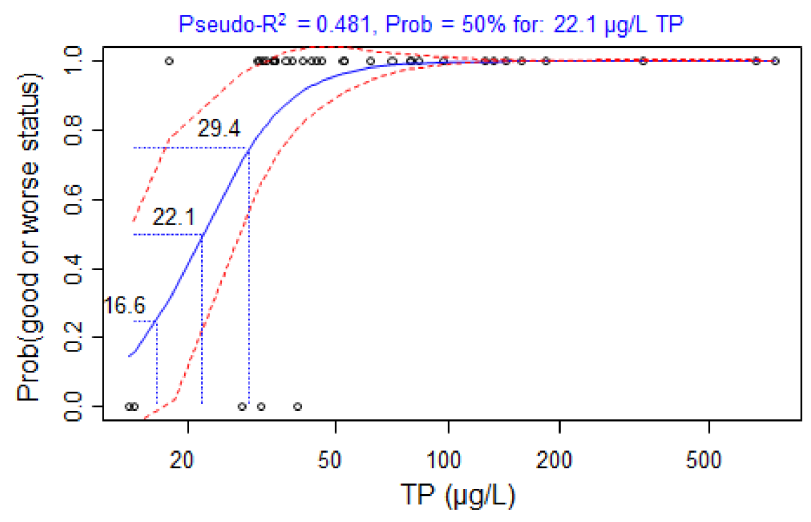

(c)

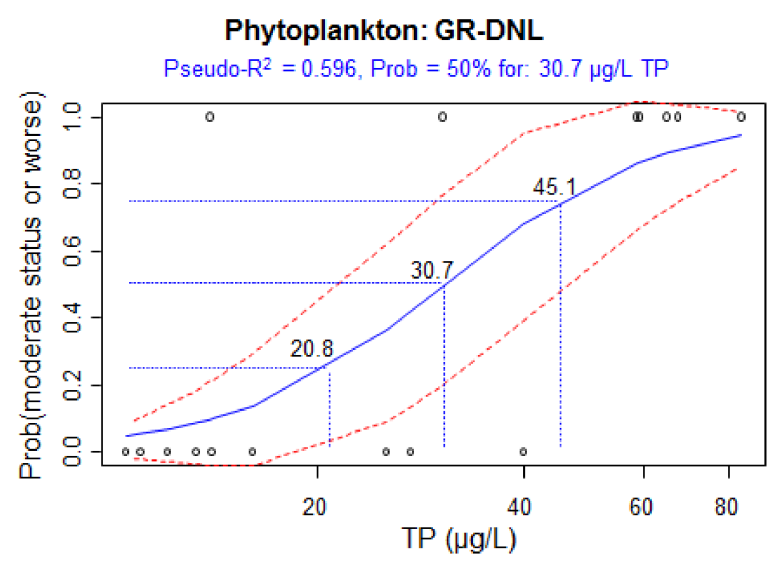

(b)

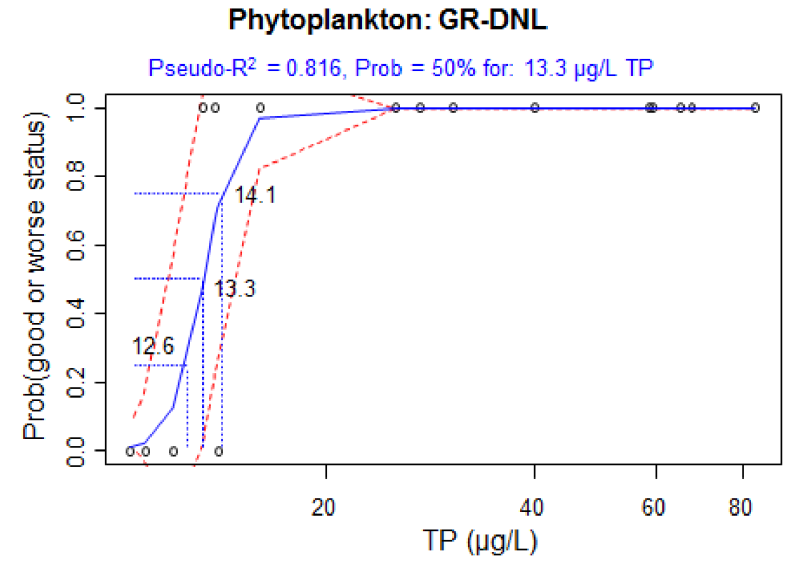

(d)

Figure 4. Binary logistic regression ( $\pm 95 \%$ confidence limits) between Total Phosphorus ( $\mu \mathrm{g} / \mathrm{L})$ and the probability of phytoplankton being classified as: $(\mathbf{a}, \mathbf{b})$ moderate or worse; $(\mathbf{c}, \mathbf{d})$ good or worse in Greek Shallow Natural Lakes (GR-SNL) and Greek Deep Natural Lakes (GR-DNL), respectively. Lines show potential good-moderate and high-good thresholds at probabilities $0.25,0.5$ and 0.75 , reflecting differing levels of precaution and intersections with fit $\pm 95 \%$ confidence limits.

\subsection{Minimisation of Mismatch of Classification}

For GR-SNL type, the mean value for good-moderate threshold was $22 \mu \mathrm{g} / \mathrm{L}$ (range: 14-36 $\mu \mathrm{g} / \mathrm{L}$ ) with a mismatch classification ranging from $12 \%$ to $28 \%$ (Figure $5 \mathrm{a}$ ). The high-good mean threshold was $19 \mu \mathrm{g} / \mathrm{L}$ (range: 14-27 $\mu \mathrm{g} / \mathrm{L}$ ) for the same lake type, which was within the range $6-16 \%$ (Figure $5 \mathrm{~b}$ ). In the case of the GR-DNL types, the mean estimated good-moderate boundary was $31 \mu \mathrm{g} / \mathrm{L}$ within a range of $21-37 \mu \mathrm{g} / \mathrm{L}$ and total mismatch classifications rate of $17 \%$ (range: 6-22\%). For high-good boundary the mean value of TP was $14 \mu \mathrm{g} / \mathrm{L}$ (range: $12-15 \mu \mathrm{g} / \mathrm{L}$ ) with relatively low rate of total mismatch $(12 \%$, range $4-16 \%)$. 


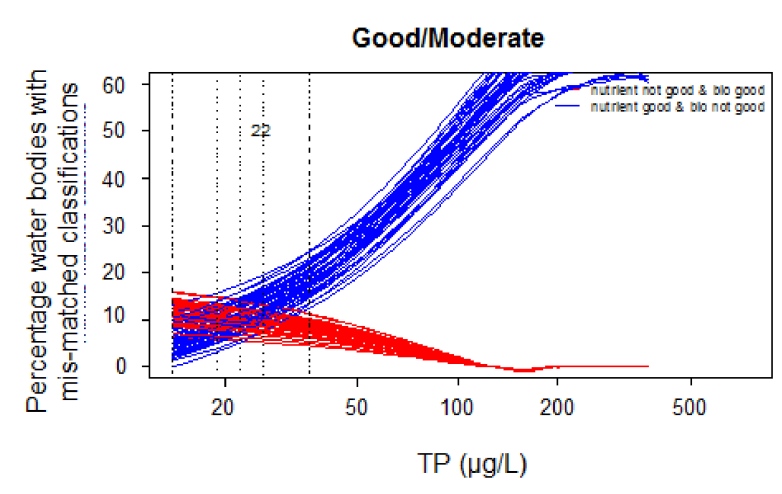

(a)

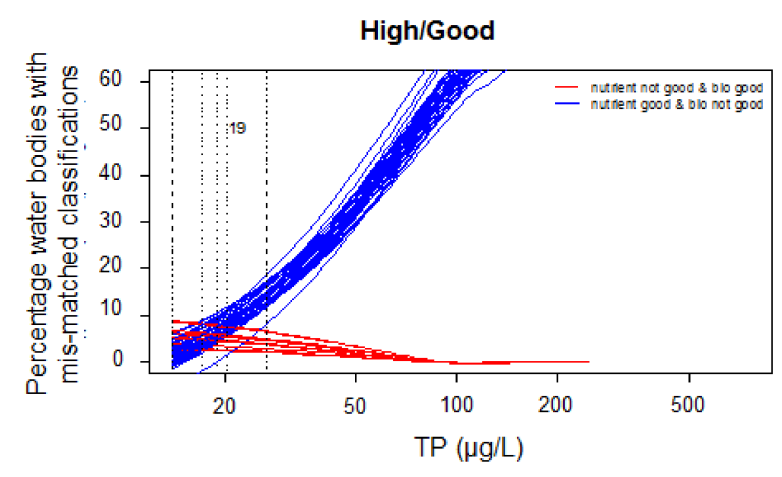

(c)

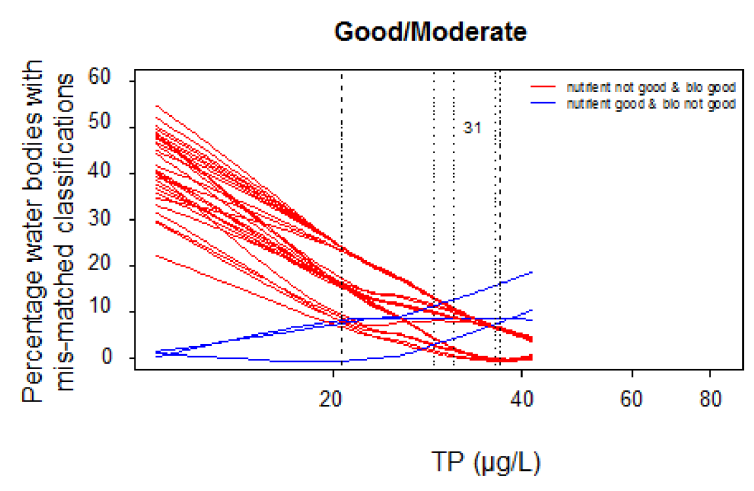

(b)

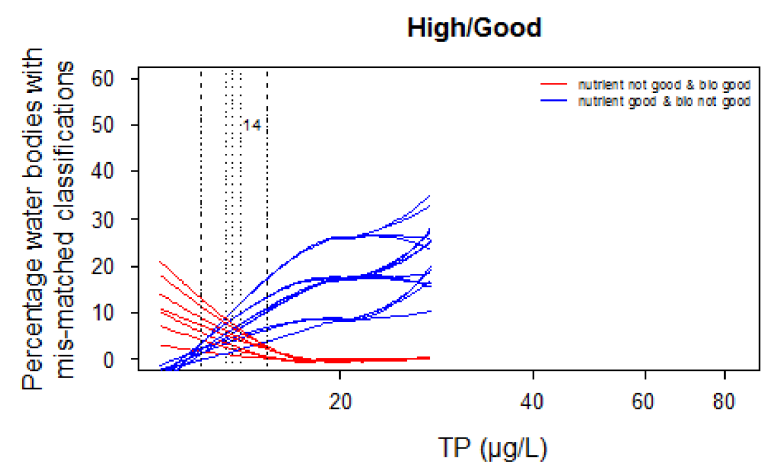

(d)

Figure 5. Percentage of water bodies where phytoplankton or Total Phosphorus (TP, $\mu \mathrm{g} / \mathrm{L}$ ) classifications for ecological status differ in comparison to the level used to set the threshold for $(\mathbf{a}, \mathbf{b})$ good-moderate or worse status; (c,d) high-good or worse status in Greek Shallow Natural Lakes (GR-SNL) and Greek Deep Natural Lakes (GR-DNL), respectively. Each line shows a sub-sample of data set selected randomly (loess models). Vertical lines mark the mean and range of intersections (minimum value, 1st quantile, median, mean, 3rd quantile, maximum value).

\subsection{Decision Trees}

The threshold value of TP for high status was $<16 \mu \mathrm{g} / \mathrm{L}$ and $<13 \mu \mathrm{g} / \mathrm{L}$, while for moderate status $\geq 42 \mu \mathrm{g} / \mathrm{L}$ and $\geq 49 \mu \mathrm{g} / \mathrm{L}$ for GR-SNL and GR-DNL types, respectively (Figure 6a,b). Only the model for GR-DNL type showed significantly better performance over the no information rate as indicated by the $p$-value (Table 3). The validation for the decision trees is presented in Figure 7. For GR-DNL, the cross validation error was minimum in three sizes of the tree, while for GR-SNL was gradually increased.

Table 3. Summary of statistics from decision trees per lake type (GR-SNL: Greek Shallow Natural Lakes and GR-DNL: Greek Deep Natural Lakes), obtained by regression analyses. NA: not applicable.

\begin{tabular}{ccc}
\hline Parameters & GR-SNL & GR-DNL \\
\hline Accuracy & 0.917 & 0.875 \\
95\% confidence interval & $0.775-0.983$ & $(0.6165,0.9845)$ \\
No-information rate & 0.806 & 0.375 \\
$p$-value & 0.061 & $<0.001$ \\
Kappa & 0.776 & 0.8129 \\
McNemar's Test $p$-Value & 0.392 & NA \\
\hline
\end{tabular}




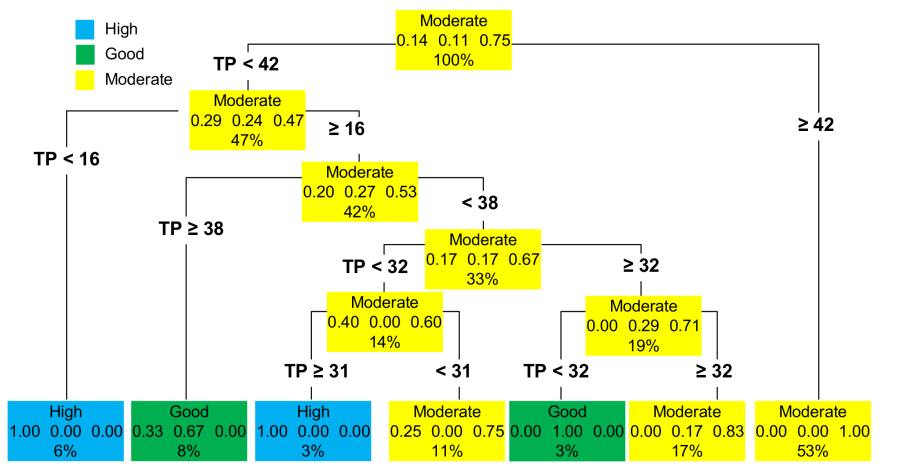

(a)

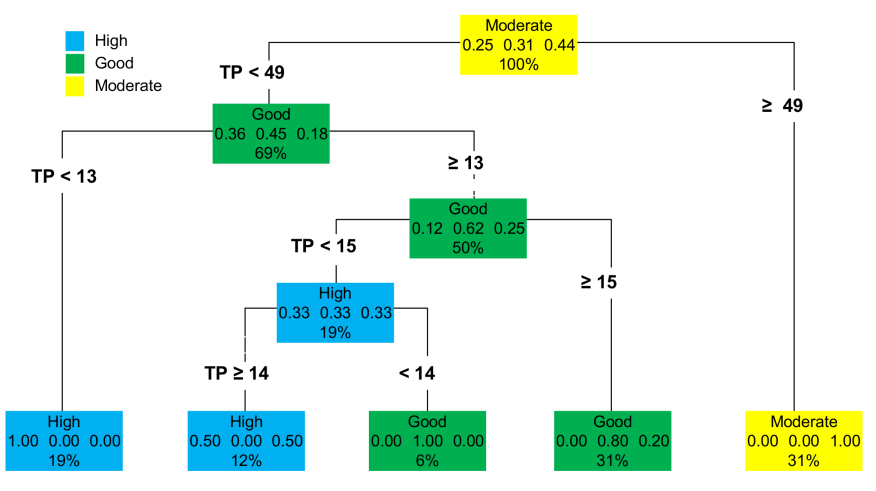

(b)

Figure 6. Classification decision trees of Total Phosphorus (TP, $\mu \mathrm{g} / \mathrm{L}$ ) on biological classes (High, Good, Moderate) based on phytoplankton in (a) Greek Shallow Natural Lakes (GR-SNL); (b) Greek Deep Natural Lakes (GR-DNL). Each node shows the predicted class, the predicted probability of each class and the percentage of observations in the node (High, Good, Moderate).

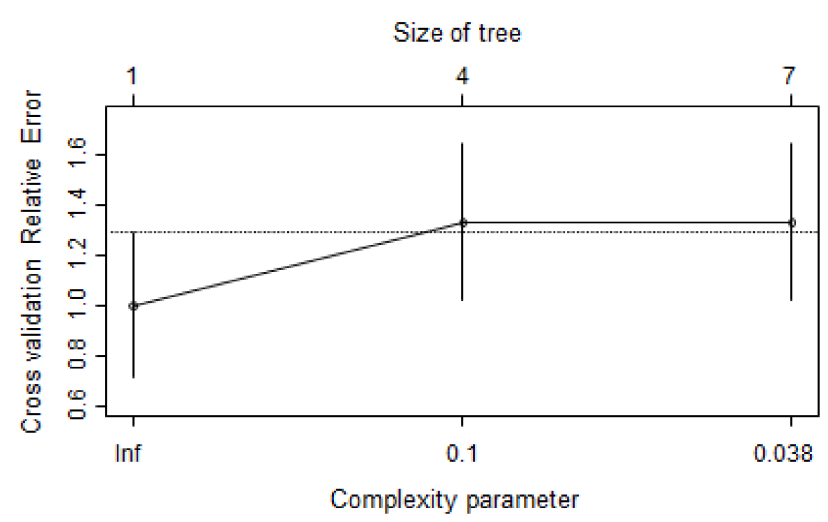

(a)

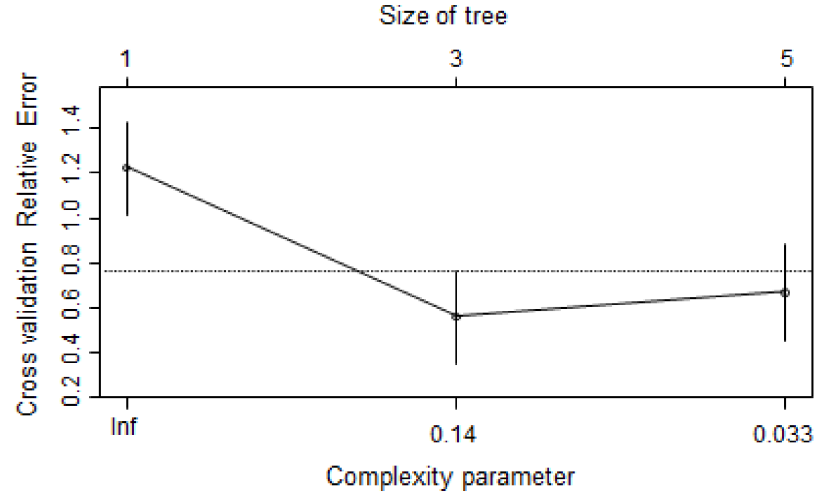

(b)

Figure 7. Cross-validation results of the decision tree for (a) Greek Shallow Natural Lakes (GR-SNL); (b) Greek Deep Natural Lakes (GR-DNL).

\subsection{Comparison of Estimated Nutrient Thresholds}

Linear regression results were significant for both lake types and thus, the first option was used to establish good-moderate and high-good TP thresholds. Among the different regression methods, we concluded that the most appropriate one was type II regression which minimizes the variation of dependent and independent variables. For both lake types, we adopted the best fit-line approach to minimize the mismatch between biological and nutrient element (Table 4). However, for GR-DNL type, the high-good threshold $(13 \mu \mathrm{g} / \mathrm{L})$ from best fit-line was almost similar with the threshold limit for reference sites $(12 \mu \mathrm{g} / \mathrm{L})$ and thus, we selected the upper quantile of regression residuals. Overall, the nutrient criteria predicted by the different approaches were similar within lake types and lower for deep natural lakes. 
Table 4. High—good (HG) and good-moderate (GM) Total Phosphorus (TP, $\mu \mathrm{g} / \mathrm{L}$ ) thresholds selected for Greek Shallow Natural Lakes (GR-SNL) and Greek Deep Natural Lakes (GR-DNL).

\begin{tabular}{|c|c|c|}
\hline \multirow{2}{*}{ Lake Type } & \multicolumn{2}{|c|}{ TP $(\mu \mathrm{g} / \mathrm{L})$} \\
\hline & HG & GM \\
\hline GR-SNL & 20 & 41 \\
\hline GR-DNL & 15 & 32 \\
\hline
\end{tabular}

\section{Discussion}

Nutrient enrichment adversely affects both structure and function of the Greek lentic systems since most of them act as sinks mainly due to low water renewal time, among others, which in turns affects the restoration and PoMs [2,10,18]. Approaches to assess the eutrophication risk based on detailed site-specific (water body) information obviously may be applied, but they are of limited use in terms of management since the mode of the BQEs responses has a high level of uncertainty $[4,56,57]$. At least it is not the appropriate approach for the early stages of any national monitoring strategy. Therefore, the maximum nutrient uptake of such water systems must be quantified at least for not deteriorating their status. This is exactly the purpose of the relative WFD literature where the toolkit [37] is used; to link the pressures posed by nutrient pollution with the sensitive (eutrophic) receivers. In this study, we coupled nutrient and especially phosphorus concentration data of several lake years from the majority of Greek natural freshwater lakes (15 out of 22), grouped in two major types. The resulting thresholds range from $20 \mu \mathrm{g} / \mathrm{L}$ (high-good) to $41 \mu \mathrm{g} / \mathrm{L}$ (good-moderate) for GR-SNL type, whereas from $15 \mu \mathrm{g} / \mathrm{L}$ (high-good) up to $32 \mu \mathrm{g} / \mathrm{L}$ (good-moderate) for GR-DNL type.

\subsection{Relationship between TP and Phytoplankton}

Phytoplankton is long considered as one of the most suitable BQE embedded in indices assessing eutrophication in lentic systems [58] due to its fast response in the nutrients pressure. Moreover, its use within the WFD toolkit (Best Practice Guide) [37] is further known to be adequate even for coastal lagoons [39]. Either way, phytoplankton is deemed as the organism group more sensitive to phosphorus and responds directly at changes of nutrient concentrations in the water column and not the sediment, like macrophytes or invertebrates [59].

Concerning the drivers of phytoplankton community structuring and inter-species relations or internal/external nutrient loading, we have to acknowledge that co-limitations of nitrogen or phosphorus are frequently postulated from enhanced growth responses following enrichment with nutrients [9] or due to a nutrient range around the Redfield ratio, making mitigation of eutrophication a rather difficult task [23]. This co-limation with temporal pattern is the case for many of the Greek lakes [60] and consists a limitation of this study due to data availability. Nonetheless, the concept of reducing just phosphorus loads for effectively addressing eutrophication or simultaneously reducing nitrogen to control cyanobacterial blooms (directly connected with status classification) is still a matter of debate $[23,61,62]$. Shallow lakes are usually subject to re-oligotrophication "experiments" by focusing on limiting phosphorus loading but they are also known to respond to nitrogen limitation for eutrophication mitigation $[21,23,63]$. In addition, deep lakes have been studied (mostly temperate ones) with adverse findings. However, it can be accepted that appropriate nutrient management strategy must be found since such kind of attempts are costly and complex $[9,64]$.

\subsection{Selection of Methodology and Thresholds' Setting}

Among the different regression methods, we concluded that the most appropriate one was type II regression where the fitting procedure minimizes the variation of both dependent and independent variables [37]. Box plots resulted in a boundary overlap in GR-SNL; thus, boundaries should be treated with caution, while in GR-DNL the predicted 
high-good thresholds were similar to reference values leaving "no room" for the ecological class. Moreover, threshold values close to reference conditions will deem the protection and management decisions of waterbodies impractical [38]. Regarding the binary logistic regression, our dataset was marginal to comply with the demands of the method; thus, underestimating the good-moderate boundary for GR-SNL type. The approach minimisation of mismatch of classification narrowed down the good status' class range (19-22 $\mu \mathrm{g} / \mathrm{L})$ in GR-SNL type, while in GR-DNL predicted TP thresholds were acceptable. Decision trees resulted in mixing the boundaries for good ecological status in GR-SNL, whereas in both types (GR-SNL and GR-DNL) high status boundaries were similar with the reference values. In our case, given that we tested the dataset for a single stressor (TP), it was expected to have more confidence in linear regression approaches [5].

Generally, too wide confidence intervals for percentiles were avoided given the large variations along with too short intervals leaving narrow range for a class status. For our selection, an essential element was the existence of threshold range within the class of high status or else the only acceptable value would be the reference one. Our interest was not solely targeted to the good-moderate boundary, as the most critical one. Relative selections of specific quantiles took place when the threshold for high-good status was really close to the reference values, like in the case of GR-DNL type. Higher quantiles assure that the response to the nutrient stressor is included in such range minimizing the risk that the regression line is "attracted by the more outlying" records given a certain pressure level [5,65].

The proposed thresholds depend on the choice of the BQE, the best fitting method and the acceptability for these limits (expert judgment). Data for other BQEs like macrophytes and macroinvertebrates were inadequate for proper statistical processing via the toolkit despite the software at hand. Poor datasets that could cause a bias and compromise the findings were not included in the analyses. Moreover, data distribution shape or lacking data from all ecological quality classes within the used dataset made some analyses unacceptable. Still there were cases where the data could not support appropriately an approach (e.g., box plots) due to limited coverage of the gradient of disturbance.

The European MSs suitable for comparison would be Cyprus, Spain and Malta who, like Greece, cannot either be linked to broad types due to peculiarities in typological descriptors [27]. Unfortunately, we could not find published data, like in the case of Greece, besides the fact they had a rising trend in concentrations the last 20 years [66]. The proposed thresholds of this study lay below the proposed thresholds by [8,9]. In Poikane et al. [28] the presented range of median values for good-moderate boundary for all types of Mediterranean lakes are from below $30 \mu \mathrm{g} / \mathrm{L}$ up to almost $50 \mu \mathrm{g} / \mathrm{L}$, which sets our thresholds within range and acceptable. Moreover, the concentration ranges within each class threshold are acceptable compared to the findings of other MSs (e.g., Irish:

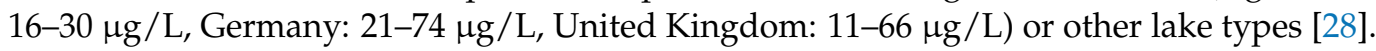

\subsection{General Commentary}

It is a common truth that dual relationships of pressure-response of nutrients and biological communities can provide an objective method for establishing nutrient concentration thresholds $[8,67]$ in support of WFD goal. In lakes, phytoplankton metrics give stronger relationships with phosphorus $[8,28,32,67]$. The above facts formed the basis of this research. Despite nutrients are supporting elements in assessing the ecological status, the determination of "solid" boundaries is necessary in the setup of proper PoMs either for monitoring or for rehabilitation. In the present study, we addressed the TP enrichment, one of the main pressures exert to lakes that affects phytoplankton community. However, for Greece, the thresholds should be updated given a more complete dataset, including nitrogen concentrations along with a study for the rest two lake types (very shallow natural lakes and reservoirs). At that point, perhaps the use of Redfield ratio could be considered as an asset/proxy for lake management. Moreover, the best practice guidance [37] could be applied for determining the thresholds of additional environmental parameters, such as 
chlorophyll-a and transparency measured as Secchi disk depth. The separately or the combined use of other BQEs [38] (e.g., macrophytes, fish and macroinvertebrates) which have already been used for the quality assessment of Greek lakes is challenging for establishing nutrient thresholds and planning strategies to achieve good ecological status and manage aquatic basins.

\section{Conclusions}

In conclusion, the proposed thresholds are realistic and supported by a complete dataset, so the present paper could be deemed as the basis for exploring eutrophication trends based on ecological knowledge, also acting as a tool for supporting the Good Ecological Status goal achievement. The establishment of phosphorous thresholds at European scale is a fact, though, direct comparisons among European MSs remains a non-realistic goal. A more extended dataset is required to update the proposed thresholds, while given the nutrient co-limitation in many Greek lakes, these should also apply to nitrogen boundaries as well.

Author Contributions: Conceptualization, I.K. and V.T.; methodology, D.K., D.L. and C.N.; software, C.N. and D.L.; formal analysis, C.N. and D.L.; data curation, D.K. and C.N.; writing-original draft preparation, C.N., D.L. and I.K.; writing — review and editing, I.K., D.L., C.N., D.C.B., D.K. and V.T.; visualization, C.N. and D.K.; supervision, I.K. and D.C.B. All authors have read and agreed to the published version of the manuscript.

Funding: The data used in this research come from Act MIS 5001204 financed by the European Union Cohesion Fund (Partnership Agreement 2014-2020), and from Acts MIS 371010, 371138, 371140, 371144,371145 financed by the European Regional Development Fund (National Strategic Reference Framework 2007-2013).

Institutional Review Board Statement: Not applicable.

Data Availability Statement: The data that support reported results of this study were used under license from The Goulandris Natural History Museum, Greek Biotope/Wetland Centre (EKBY). They are available upon reasonable request from D.K. and with permission of The Goulandris Natural History Museum, Greek Biotope/Wetland Centre (EKBY).

Acknowledgments: The present study was conducted in the frame of the Greek National Water Monitoring Network, according to the JMD 140384/2011, implemented by The Goulandris Natural History Museum, Greek Biotope/Wetland Centre (EKBY). The network is supervised by the General Directorate for Waters of the Ministry of Environment and Energy. EKBY's personnel conducted samplings and contributed to sample analysis. Part of phytoplankton analysis was commissioned to AUTH.

Conflicts of Interest: The funders had no role in the design of the study; in the collection, analyses, or interpretation of data; in the writing of the manuscript, or in the decision to publish the results.

\section{References}

1. European Communities. Directive 2000/60/EC of the European Parliament and of the Council of 23 October 2000 establishing a framework for community action in the field of water policy. Off. J. Eur. Communities 2000, L327, 1-72.

2. MARS Project (Managing Aquatic Ecosystems and Water Resources under Multiple Stress). Available online: http:/ /www.marsproject.eu/ (accessed on 22 December 2020).

3. Nõges, P.; Argillier, C.; Borja, A. Deliverable 2.1-Four Manuscripts on the Multiple Stressor Framework. Part 1: Review of Multiple Stressors and Their Effects on European Surface Waters; MARS project: Essen, Germany, 2015; 288p.

4. Nõges, P.; Argillier, C.; Borja, Á.; Garmendia, J.M.; Hanganu, J.; Kodeš, V.; Pletterbauer, F.; Sagouis, A.; Birk, S. Quantified biotic and abiotic responses to multiple stress in freshwater, marine and ground waters. Sci. Total Environ. 2016, 540, 43-52. [CrossRef] [PubMed]

5. Phillips, G.; Teixeira, H.; Poikane, S.; Herrero, F.S.; Kelly, M.G. Establishing nutrient thresholds in the face of uncertainty and multiple stressors: A comparison of approaches using simulated datasets. Sci. Total Environ. 2019, 684, 425-433. [CrossRef] [PubMed]

6. Birk, S.; Willby, N.J.; Kelly, M.G.; Bonne, W.; Borja, A.; Poikane, S.; Van de Bund, W. Intercalibrating classifications of ecological status: Europe's quest for common management objectives for aquatic ecosystems. Sci. Total Environ. 2013, 454, 490-499. [CrossRef] 
7. Poikane, S.; Portielje, R.; van den Berg, M.; Phillips, G.; Brucet, S.; Carvalho, L.; Mischke, U.; Ott, I.; Soszka, H.; Van Wichelen, J. Defining ecologically relevant water quality targets for lakes in Europe. J. Appl. Ecol. 2014, 51, 592-602. [CrossRef]

8. Dolman, A.M.; Mischke, U.; Wiedner, C. Lake-type-specific seasonal patterns of nutrient limitation in German lakes, with target nitrogen and phosphorus concentrations for good ecological status. Freshw. Biol. 2016, 61, 444-456. [CrossRef]

9. Poikane, S.; Phillips, G.; Birk, S.; Free, G.; Kelly, M.G.; Willby, N.J. Deriving nutrient criteria to support 'good' ecological status in European lakes: An empirically based approach to linking ecology and management. Sci. Total Environ. 2019, 650, 2074-2084. [CrossRef] [PubMed]

10. Stefanidis, K.; Papaioannou, G.; Markogianni, V.; Dimitriou, E. Water quality and hydromorphological variability in Greek rivers: A nationwide assessment with implications for management. Water 2019, 11, 1680. [CrossRef]

11. Hering, D.; Borja, A.; Carstensen, J.; Carvalho, L.; Elliott, M.; Feld, C.K.; Heiskanen, A.S.; Johnson, R.K.; Moe, J.; Pont, D.; et al. The European Water Framework Directive at the age of 10: A critical review of the achievements with recommendations for the future. Sci. Total Environ. 2010, 408, 4007-4019. [CrossRef]

12. Elosegi, A.; Gessner, M.O.; Young, R.G. River doctors: Learning from medicine to improve ecosystem management. Sci. Total Environ. 2017, 595, 294-302. [CrossRef]

13. Voulvoulis, N.; Arpon, K.D.; Giakoumis, T. The EU Water Framework Directive: From great expectations to problems with implementation. Sci. Total Environ. 2017, 575, 358-366. [CrossRef] [PubMed]

14. Poikane, S.; Zampoukas, N.; Borja, A.; Davies, S.P.; van de Bund, W.; Birk, S. Intercalibration of aquatic ecological assessment methods in the European Union: Lessons learned and way forward. Environ. Sci. Policy 2014, 44, 237-246. [CrossRef]

15. Poikane, S.; Birk, S.; Böhmer, J.; Carvalho, L.; de Hoyos, C.; Gassner, H.; Hellsten, S.; Kelly, M.; Solheim, A.L.; Olin, M.; et al. A hitchhiker's guide to European lake ecological assessment and intercalibration. Ecol. Indic. 2015, 52, 533-544. [CrossRef]

16. Dodds, W.K.; Oakes, R.M. A technique for establishing reference nutrient concentrations across watersheds affected by humans. Limnol. Oceanogr. Methods 2004, 2, 333-341. [CrossRef]

17. Hausmann, S.; Charles, D.F.; Gerritsen, J.; Belton, T.J. A diatom-based biological condition gradient (BCG) approach for assessing impairment and developing nutrient criteria for streams. Sci. Total Environ. 2016, 562, 914-927. [CrossRef]

18. Skoulikidis, N. The State and Origin of River Water Composition in Greece. In The Rivers of Greece; Skoulikidis, N., Dimitriou, E., Karaouzas, I., Eds.; The Handbook of Environmental Chemistry; Springer: Berlin/Heidelberg, Germany, 2016 ; Volume 59.

19. Vuorio, K.; Järvinen, M.; Kotamäki, N. Phosphorus thresholds for bloom-forming cyanobacterial taxa in boreal lakes. Hydrobiologia 2020, 847, 4389-4400. [CrossRef]

20. Weber, S.J.; Mishra, D.R.; Wilde, S.B.; Kramer, E. Risks for cyanobacterial harmful algal blooms due to land management and climate interactions. Sci. Total Environ. 2020, 703, 134608. [CrossRef]

21. Jeppesen, E.; Søndergaard, M.; Jensen, J.P.; Havens, K.E.; Anneville, O.; Carvalho, L.; Coveney, M.F.; Deneke, R.; Dokulil, M.T.; Foy, B.O.B.; et al. Lake responses to reduced nutrient loading-an analysis of contemporary long-term data from 35 case studies. Freshw. Biol. 2005, 50, 1747-1771. [CrossRef]

22. Jilbert, T.; Couture, R.M.; Huser, B.J.; Salonen, K. Preface: Restoration of eutrophic lakes: Current practices and future challenges. Hydrobiologia 2020, 847, 4343-4357. [CrossRef]

23. Chorus, I.; Spijkerman, E. What Colin Reynolds could tell us about nutrient limitation, N: P ratios and eutrophication control. Hydrobiologia 2021, 848, 95-111. [CrossRef]

24. Marttila, H.; Lepistö, A.; Tolvanen, A.; Bechmann, M.; Kyllmar, K.; Juutinen, A.; Wenng, H.; Skarbøvik, E.; Futter, M.; Kortelainen, P.; et al. Potential impacts of a future Nordic bioeconomy on surface water quality. Ambio 2020, 49, 1722-1735. [CrossRef]

25. Tong, Y.; Wang, M.; Peñuelas, J.; Liu, X.; Paerl, H.W.; Elser, J.J.; Sardans, J.; Couture, R.M.; Larssen, T.; Hu, H.; et al. Improvement in municipal wastewater treatment alters lake nitrogen to phosphorus ratios in populated regions. Proc. Natl. Acad. Sci. USA 2020, 117, 11566-11572. [CrossRef] [PubMed]

26. EEA (European Environment Agency). European Waters. Assessment of Status and Pressures 2018. In EEA report 7/2018; Publications Office of the European Union: Luxembourg, 2018.

27. Solheim, A.L.; Globevnik, L.; Austnes, K.; Kristensen, P.; Moe, S.J.; Persson, J.; Phillips, G.; Poikane, S.; van de Bund, W.; Birk, S. A new broad typology for rivers and lakes in Europe: Development and application for large-scale environmental assessments. Sci. Total Environ. 2019, 697, 134043. [CrossRef] [PubMed]

28. Poikane, S.; Kelly, M.G.; Herrero, F.S.; Pitt, J.A.; Jarvie, H.P.; Claussen, U.; Leujak, W.; Solheim, A.L.; Teixeira, H.; Phillips, G. Nutrient criteria for surface waters under the European Water Framework Directive: Current state-of-the-art, challenges and future outlook. Sci. Total Environ. 2019, 695, 133888. [CrossRef]

29. Trolle, D.; Hamilton, D.P.; Pilditch, C.A.; Duggan, I.C.; Jeppesen, E. Predicting the effects of climate change on trophic status of three morphologically varying lakes: Implications for lake restoration and management. Environ. Model. Softw. 2011, 26, 354-370. [CrossRef]

30. Katsev, S. When large lakes respond fast: A parsimonious model for phosphorus dynamics. J. Great Lakes Res. 2017, 43, 199-204. [CrossRef]

31. Carvalho, L.; Mackay, E.B.; Cardoso, A.C.; Baattrup-Pedersen, A.; Birk, S.; Blackstock, K.L.; Borics, G.; Borja, A.; Feld, C.K.; Ferreira, M.T.; et al. Protecting and restoring Europe's waters: An analysis of the future development needs of the Water Framework Directive. Sci. Total Environ. 2019, 658, 1228-1238. [CrossRef] 
32. Carvalho, L.; McDonald, C.; de Hoyos, C.; Mischke, U.; Phillips, G.; Borics, G.; Poikane, S.; Skjelbred, B.; Solheim, A.L.; Van Wichelen, J.; et al. Sustaining recreational quality of European lakes: Minimizing the health risks from algal blooms through phosphorus control. J. Appl. Ecol. 2013, 50, 315-323. [CrossRef]

33. Phillips, G.; Pitt, J.A. A Comparison of European Freshwater Nutrient Boundaries Used for the Water Framework Directive: A Report to WG ECOSTAT; Ensis Ltd.: London, UK, 2016; 195p.

34. Reynolds, C.S.; Irish, A.E.; Elliott, J.A. The ecological basis for simulating phytoplankton responses to environmental change (PROTECH). Ecol. Modell. 2001, 140, 271-291. [CrossRef]

35. Davies, S.P.; Jackson, S.K. The biological condition gradient: A descriptive model for interpreting change in aquatic ecosystems. Ecol. Appl. 2006, 16, 1251-1266. [CrossRef]

36. Moss, B. Ecology of Fresh Waters: A View for the Twenty-First Century, 4th ed.; Ohn Wiley \& Sons: Oxford, UK, 2010; 470p.

37. Phillips, G.; Kelly, M.; Teixeira, H.; Salas, F.; Free, G.; Leujak, W.; Solheim, A.L.; Várbíró, G.; Poikane, S. Best Practice for Establishing Nutrient Concentrations to Support Good Ecological Status. In Technical Report EUR 29329, EN.; Publications Office of the European Union: Luxembourg, 2018; p. 142.

38. Poikane, S.; Várbíró, G.; Kelly, M.G.; Birk, S.; Phillips, G. Estimating river nutrient concentrations consistent with good ecological condition: More stringent nutrient thresholds needed. Ecol. Indic. 2021, 121, 107017. [CrossRef]

39. Salas Herrero, F.; Teixeira, H.; Poikane, S. A novel approach for deriving nutrient criteria to support good ecological status: Application to coastal and transitional waters and indications for use. Front. Mar. Sci. 2019, 6, 255. [CrossRef]

40. European Commission. Commission Decision (EU) 2018/229 of 12 February 2018 establishing, pursuant to Directive 2000/60/EC of the European Parliament and of the Council, the values of the Member State monitoring system classifications as a result of the intercalibration exercise and repealing Commission Decision 2013/480/EU. Off. J. Eur. Communities 2018, 47, 1-91.

41. River Basin Management Plans. Available online: http:/ /wfdver.ypeka.gr/en/home-en/ (accessed on 27 December 2020).

42. Kagalou, I.; Latinopoulos, D. Filling the Gap between Ecosystem Services Concept and River Basin Management Plans: The Case of Greece in WFD 20+. Sustainability 2020, 12, 7710. [CrossRef]

43. Maia, R. The WFD implementation in the European member states. Water Resour. Manag. 2017, 31, 3043-3060. [CrossRef]

44. Tsiaoussi, V.; Mavromati, E.; Kemitzoglou, D. Report on the Development of the National Method for the Assessment of the Ecological Status of Natural Lakes in Greece, Using the Biological Quality Element "Phytoplankton", 1st ed.; Greek Biotope/Wetland Centre and Special Secretariat for Waters, Ministry of Environment: Thermi, Greece, 2017; p. 17.

45. Ntislidou, C.; Lazaridou, M.; Tsiaoussi, V.; Bobori, D.C. A new multimetric macroinvertebrate index for the ecological assessment of Mediterranean lakes. Ecol. Indic. 2018, 93, 1020-1033. [CrossRef]

46. Mavromati, E.; Kemitzoglou, D.; Tsiaoussi, V.; Lazaridou, M. Report on the Development of the National Method for the Assessment of Ecological Status of Natural Lakes in Greece, with the Use of Littoral Benthic Invertebrates; Greek Biotope/Wetland Centre and Special Secretariat for the Natural Environment and Waters, Ministry of Environment and Energy: Thermi, Greece, $2020 ;$ p. 11.

47. Petriki, O.; Lazaridou, M.; Bobori, D.C. A fish-based index for the assessment of the ecological quality of temperate lakes. Ecol. Indic. 2017, 78, 556-565. [CrossRef]

48. Zervas, D.; Tsiaoussi, V.; Tsiripidis, I. HeLM: A macrophyte-based method for monitoring and assessment of Greek lakes. Environ. Monit. Assess. 2018, 190, 326. [CrossRef] [PubMed]

49. de Hoyos, C.; Catalan, J.; Dörflinger, G.; Ferreira, J.; Kemitzoglou, D.; Laplace-Treyture, C.; López, P.J.; Marchetto, A.; Mihail, O.; Morabito, G.; et al. Mediterranean Lake Phytoplankton Ecological Assessment Methods; Water Framework Directive Intercalibration Technical Report; Publications Office of the European Union: Luxembourg, 2014; p. 70.

50. Armitage, P.D.; Hogger, J. Invertebrate ecology and survey. In The New Rivers and Wildlife Handbook, 1st ed.; Ward, D., Holmes, N., Jose, P., RSPB, NRA, RSN, Eds.; RSPB Sandy: Bedfordshire, UK, 1994; Volume 1, pp. 151-159.

51. ISEN 15460. Water Quality-Guidance Standard for the Surveying of Macrophytes in Lakes; BSI: Brussels, Belgium, $2007 ;$ p. 24.

52. Kolada, A.; Hellsten, S.; Kanninen, A.; Søndergaard, M.; Dudley, B.; Nõges, P.; Ott, I.; Ecke, F.; Mjelde, M.; Penning, E.; et al. Overview and Comparison of Macrophyte Survey Methods Used in European Countries and a Proposal of Harmonized Common Sampling Protocol to Be Used for WISER Uncertainty Exercise Including a Relevant Common Species List. Wiser Deliverable D3.2-1: 2009. Available online: http:/ / www.wiser.eu/results/deliverables/ (accessed on 5 September 2017).

53. APHA; AWWA. WEF. In Standard Methods for Examination of Water and Waste Water, 22nd ed.; American Public Health Association: Washington, DC, USA, 2012; p. 1360.

54. R Core Team. R: A Language and Environment for Statistical Computing; R Foundation for Statistical Computing: Vienna, Austria, 2019; Available online: https:/ / www.R-project.org/ (accessed on 10 November 2020).

55. Smith, R.J. Use and misuse of the reduced major axis for line-fitting. Am. J. Phys. Anthropol. 2009, 140, 476-486. [CrossRef]

56. Bennion, H.; Hilton, J.; Hughes, M.; Clark, J.; Hornby, D.; Fozzard, I.; Phillips, G.; Reynolds, C. The use of a GIS-based inventory to provide a national assessment of standing waters at risk from eutrophication in Great Britain Sci. Total Environ. 2005, 344, 259-273. [CrossRef]

57. O'Hare, M.T.; Baattrup-Pedersen, A.; Baumgarte, I.; Freeman, A.; Gunn, I.D.M.; Lázár, A.N.; Wade, A.J.; Bowes, M.J. Responses of aquatic plants to eutrophication in rivers: A revised conceptual model. Front. Plant Sci. 2018, 9, 451. [CrossRef] [PubMed]

58. Smith, V.H.; Bennett, S.J. Nitrogen: Phosphorus supply ratios and phytoplankton community structure in lakes. Arch. Hydrobiol. 1999, 16, 37-53. [CrossRef] 
59. Birk, S.; Chapman, D.; Carvalho, L.; Spears, B.M.; Andersen, H.E.; Argillier, C.; Auer, S.; Baattrup-Pedersen, A.; Banin, L.; Beklioğlu, M.; et al. Impacts of multiple stressors on freshwater biota across spatial scales and ecosystems. Nat. Ecol. Evol. 2020, 4, 1060-1068. [CrossRef]

60. Latinopoulos, D.; Ntislidou, C.; Kagalou, I. Multipurpose plans for the sustainability of the Greek lakes: Emphasis on multiple stressors. Environ. Process. 2016, 3, 589-602. [CrossRef]

61. Paerl, H.W.; Otten, T.G. Duelling 'CyanoHABs': Unravelling the environmental drivers controlling dominance and succession among diazotrophic and non-N2-fixing harmful cyanobacteria. Environ. Microbiol. 2016, 18, 316-324. [CrossRef]

62. Paerl, H.W.; Havens, K.E.; Xu, H.; Zhu, G.; McCarthy, M.J.; Newell, S.E.; Scott, J.T.; Hall, N.S.; Otten, T.G.; Qin, B. Mitigating eutrophication and toxic cyanobacterial blooms in large lakes: The evolution of a dual nutrient $(\mathrm{N}$ and $\mathrm{P}$ ) reduction paradigm. Hydrobiologia 2020, 847, 4359-4375. [CrossRef]

63. Lampert, W.; Sommer, U. Limnoecology: The Ecology of Lakes and Streams, 2nd ed.; Oxford University Press: Oxford, UK, 2007; 324p.

64. Schindler, D.W. The dilemma of controlling cultural eutrophication of lakes. Proc. Biol. Sci. 2012, 279, 4322-4333. [CrossRef]

65. Koenker, R. Additive models for quantile regression: Model selection and confidence bandaids. Braz. J. Probab. Stat. 2011, 25, 239-262. [CrossRef]

66. European Environment Agency. Available online: https://www.eea.europa.eu/data-and-maps/indicators/nutrients-infreshwater (accessed on 27 December 2020).

67. Phillips, G.; Solheim, A.L.; Skjelbred, B.; Mischke, U.; Drakare, S.; Free, G.; Järvinen, M.; de Hoyos, C.; Morabito, G.; Poikane, S.; et al. A phytoplankton trophic index to assess the status of lakes for the Water Framework Directive. Hydrobiologia 2013, 704, 75-95. [CrossRef] 